of the Mbunda, people of Angola origins who have lived in the Barotse province for more than I 50 years. It is intended to carry out further studies on the position of the craftsman in Mbunda society and the significance of the crafts produced. As a result of a long historical evolution the Mbunda produce crafts traditional to their own culture, others derived from the cultures of neighbouring tribes, and objects for the curio trade. The craftsmen will be studied in relation to this historical background both individually and socially. The techniques used in producing the crafts and how the crafts are utilized will also be studied.

(Communicated by P. André Vrydagh, Keeper of Ethnography)

\title{
Recent Research at the Nigerian Institute of Social and Economic Research, University of Ibadan
}

AN account of the activities of the N.I.S.E.R., University of Ibadan, is given in its Information Bulletin, No. 3, February 1968 . When the Institute was reorganized in 1964 a new research programme was initiated which gave priority to those projects most relevant to Nigeria's economic and social development. Among studies already completed are: Studies in the Staple Food Economy of Western Nigeria (R. Guesten), an aspect of a larger project on the marketing of staple agricultural products in Nigeria, which is being prepared for publication; The History of the Co-operative Movement in Nigeria (S. O. Adeyeye); and other studies on aspects of Nigerian economy, trade, and investment. Projects on which field work has been completed include: Survey of Fertility and Income in Nigeria (P. O. Olusanya); Differential Fertility in Selected Areas of Ibadan (F. O. Okediji); The Role of the Small Town (Shagamu) in the Economic Development of Nigeria (A. L. Mabogunje); Attitudes towards the City: The Example of Iwo (P. D. Milone); Socio-Economic Research in the Kainji Lake Region, a project directed by A. L. Mabogunje dealing with the problem of changing the present fishing population into commercial fishermen on the future lake; Organization of Markets and the Marketing of Foodstuffs in Northern Nigeria (Polly Hill). Field work is also in progress on several projects concerning the Nigerian economy and on economic development and rural improvement. During the next two years the Institute's research programme will give special attention to three immediate problems: (i) economic and social reconstruction following the civil war; (ii) preparation of the second National Development Plan; (iii) economic and social problems arising from the creation of new States.

\section{Second Meeting of Social Research Fieldworkers in North-Eastern Africa}

THE second meeting of this group, organized by the Institute of Ethiopian Studies and the Department of Anthropology and Sociology of Haile Sellassie I University, was held in Addis Ababa from 20 to $2 \pi$ March under the chairmanship of Professor William Shack. It was organized by Professors Georges Savard, Alvin Rose, and Richard Pankhurst of Haile Sellassie I University.

The papers presented and discussed included 'The Linguist and the Social Scientist' by Professor Wolf Leslau; 'The Osseous Characteristics of the Femur and Tibia Indicating Race or Malnutrition' by Professor Peter Lisowski, Associate Professor; 'A Archaeological Research in Ethiopia ' by Dr. R. Schneider; ' Patterns of Thinking in Ethiopian Students' by Dr. R. Giel; 'The Economics of Handicrafts in Sidamo and Gemu Gofa' by Professor D. Karsten; ' Patterns of Marriage in a Roadside Town in South-Western Ethiopia' by Professor I. N. van Luyk; 'Governmental Recognition of Non-Governmental Legal Institutions and Laws' by Professor Norman Singer; 'Social and Religious Institutions of the Sidamo ' by Dr. S. Stanley; 'Some Thoughts on the Problem of Utbanization in PreTwentieth Century Ethiopia' by Dr. Akalu Wolde Mikael; 'Function of Sexuality and 